\title{
Highly contentious issues in the South African political and socio-economic domain
}

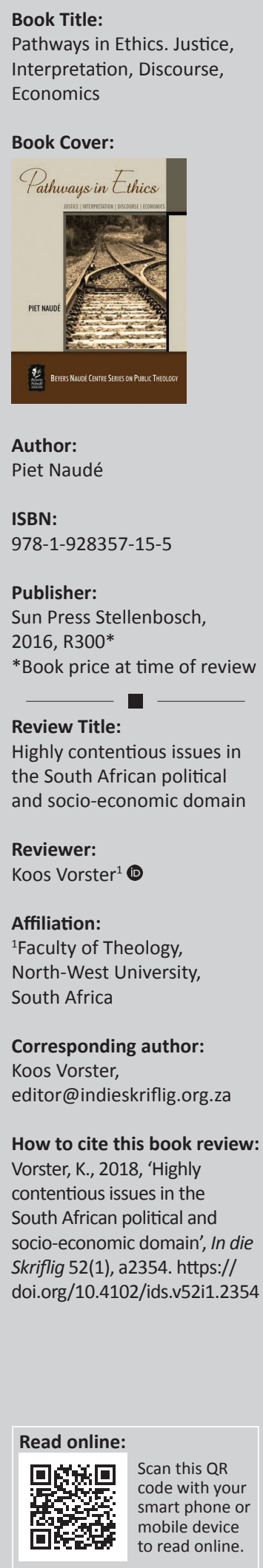

Review Title:

Highly contentious issues in the South African political and socio-economic domain

Reviewer:

Koos Vorster ${ }^{1}$

Affiliation:

${ }^{1}$ Faculty of Theology,

North-West University,

South Africa

Corresponding author: Koos Vorster, editor@indieskriflig.org.za

How to cite this book review: Vorster, K., 2018, 'Highly contentious issues in the South African political and socio-economic domain', In die Skriflig 52(1), a2354. https:// doi.org/10.4102/ids.v52i1.2354

\section{Read online:}

Scan this QR
code with your
smart phone or
mobile device
to read online.

This new book by Piet Naudé in the Beyers Naudé Series on Public Theology, contains four main parts namely Ethics, Justice and Humanity; Ethics and Interpretation; Ethics and Moral Discourse; and Ethics, Business and Economics. Every part consists of four chapters which are a compilation of earlier published articles and presentations. However, the book is divided in four different parts, it forms a unity with logical argumentation. The first chapter deals with Ethics, Justice and Humanity, and in this discussion the author makes a case for the importance of identity, being and cultural justice. He contends that cultural justice should precede social justice. Seen from a Christian ethical perspective the quest for identity can be founded in the life of the historical Jesus and his total revival of relationships.

In chapter 2 titled 'In defense of Partisan Justice', he defends the Christian notion of God's and Christ's preference for the poor from a philosophical and economic perspective. God 'on the side of the poor' is not only a theological slogan or 'church talk'. With reference to Rawls and Stiglitz he concludes that the option for the poor is an inclusive strategy worthy of universal support, taking into account features like, among others, cultural justice, participatory justice and fair trade for the poor. In the following chapter about explicating human rights from a Christian perspective, he deals with a Christian perspective on human rights. He proposes new insights with reference to various ecclesiastical testimonies on the issue. In spite of this contribution the argumentation can be considered to be rather weak in the presentation of the meaning of deep-rooted biblical themes regarding an ethos of human rights. Here the implications of concepts such as the Decalogue, kingdom of God and the covenant come to mind. The ground-breaking work of Braulik about the relevance of Deuteronomy for the foundation of the Universal Declaration of Human Rights is also neglected.

Chapter 4 presents an interesting African reflection on humanisation. A lengthy explanation of dehumanisation, especially with regard to Africa, is followed by an attempt to outline the parameters of humanisation on the foundation of the dictum $u b u n t u$. This implies a return to God as creator and judge, and the idea of the merciful God, because only 'God can turn Cain into a blessing for himself. Why not Africa also?' He succeeds to provide a theological framework for the rehumanisation of oppressed societies - also for Africa (p. 61).

The second part of the book discusses under various headings the 'Ethics of Interpretation' (chap. 5-8). In chapter 5 he warns against the fragmentation of theology and the isolation of disciplines. He pleads for multi-disciplinary, trans-disciplinary and post-disciplinary research and argues that theology can play a major role in these ventures. He emphasises in view of the post-positivistic paradigm that knowledge is relative and the last word can never be spoken. Therefore, transdisciplinary, multidisciplinary and post-disciplinary research became essential.

Chapter 6 deviates from the topic ethics and pursues the question why the reformed tradition is prone to the formulation of Confessions. With reference to Jonker, Calvin and Barth the author enlightens the role of context in the formulation of dogma and ethics. The reformed tradition regards Scripture and only Scripture as authoritative, but re-interpretation in view of the problems of a new context may become necessary. Therefore, 'because the church stands in the power of the spirit and the Word - as specifically interpreted in Reformed circles - there will always be further confessions' (p. 88).

The following chapter deals with the unresponsiveness of New Testament studies in South Africa in the public domain. The author is of the opinion that: '... we need to engage in self-critical reflection on our social location and the interest served by our scholarship' (p. 94). He discerns an avoidance of concrete ethical issues in New Testament research in South Africa and then

Copyright: ( 2018. The Authors. Licensee: AOSIS. This work is licensed under the Creative Commons Attribution License. 
rightly asks the question whether New Testament scholarship in South Africa has made a significant contribution to a contextual Christian ethics.

The last chapter of this section focuses on the question why Christian legitimacy is sometimes granted to inhuman racist systems as was apparent in the South African policy of Apartheid. The question is dealt with in view of Mark 8:27 dealing with the question about the real identity of Christ. The real identity of Christ as the Messiah and the risen Christ makes an institutionalisation of the individual notions of Christ impossible. The hope for the liberation from an ideological faith is to be found in the meeting with the resurrected Christ. In the following section titled 'Ethics and moral discourse' the author deals first of all with the moral discourse in the Accra Confession under the title: 'What has Accra to do with New York?' In view of Gustafson's varieties of moral discourse he evaluates the Accra confession on economic justice and concludes that, although this document has positive points seen as a prophetic, moral and narrative discourse, its lacks credibility in the area of policy discourse. He proposes several statements to strengthen the deficiency in the policy discourse. Perhaps a deeper evaluation of the ideological premise of the document would have added value to the chapter as a whole due to the Accra confession's very potent rejection of neo-liberalism.

Chapter 10 deals with the question whether prophetic discourse is adequate to address global economic justice. The author commences with an outline of five possible features of 'prophetic discourse'. In view of these he evaluates Gutierrez's 'preferential option for the poor'; Rawls's concept of justice as fairness in a theory of prioritarian distributive justice; Stiglitz's idea of 'fair trade for the poor' and the notion of 'special and differential treatment of developing countries' (Art. 13 of the Doha Ministerial Declaration, World Trade Organisation). Revisiting the Accra Confession, he concludes that prophetic discourse has several weaknesses such as being weak on moral analysis and silence on traditional measures. '... Taken by itself it is not an adequate form of moral discourse to actually address concrete matters of justice' (p. 145). In a discussion of the economic-ethical perspectives of the work of Etienne de Villiers titled: 'Virtue and responsibility' (chap. 11) the author honours and criticises De Villiers's contribution to Theological Ethics in South Africa by way of six statements. He commends the development in the thinking of De Villiers which departed from a pious spiritual persuasion to a responsible social ethics in dialogue with modernism and secularism.

The author then provides a South African perspective on models of how we speak of happiness. He distinguished between three models of happiness in South Africa. The first model is the Apartheid model founded on neo-Calvinism (Kuyper); Warneck's theory of mission (Völkerbekehrung); and the Scottish Pietism. The second is the 'Ubuntu' of African cultures and the third is the modernist model (the rational pursuit of self-interest). However, all these models have certain weaknesses. Therefore, with reference to Psalm 1, he proposed a fourth model as a corrective to the other three which is well described by the words of the Psalm: '... Blessed is the man who finds his joy in the Law of the Lord ...'. The faithful find joy in the Lord, irrespective of the situation and are blessed in the service of others, especially the weak and the marginalised (p. 165).

The fourth part of the book (Ethics business and economics) commences with a study on 'Ethics education in accounting'. Naudé makes a clear case that ethics should be taught to students in the field of accounting and then proposes valuable answers to the questions: 'Can ethics be taught?'; 'What should be taught?'; and 'How is ethics to be taught?' He is convinced of the absolute necessity of ethics training in this profession and recommends a convincing approach to this endeavour.

In the following chapter 'Transparency and corporate social responsibility: A South African perspective', Naudé outlines the South African instruments regarding transparency and social responsibility. In this respect he describes the references to transparency in the new South African constitution and the SRI Index of the Johannesburg Stock Exchange as well as the third King Report. He concludes that 'South Africa is indeed an interesting case study of global policies that address issues of transparency and corporate responsibility.' (p. 193). This chapter was published as an essay in 2009 and the question can be raised whether the author is still as optimistic in 2018 taking into account the waves of corruption that hit South Africa under the Zuma administration. Surely the lack of transparency and social responsibility in this era cannot be seen as a good testimony of the state of affairs in South Africa today.

The following study deals with fair global trade - a perspective from Africa. After discussing the factors, which impeded the economic growth of previous colonies such as the slave trade, colonialism and the deficiencies of postcolonial Africa, Naudé argues a case for preferential treatment for African countries in global trade. He founds this point of view in the idea of distributive justice as a sound ethical principle within the framework of unequal and previously oppressive systems.

In the last chapter Naudé focuses on economic policy and theological reflection in South Africa. He explains briefly the various economic policy documents adopted by South African governments since 1994 and concludes that generally the outcomes of these policies were not positive looking at poverty, inequality and unemployment. He then considers the role theology can play in the economic discourses. He concludes that theology as an effective public theology can add value to some criteria such as a clear understanding of human dignity, the perspective of the poor and the suffering as point of departure in economic planning and the integrity of creation. Eventually the author outlines what is meant by a public theology that can address economic policy. 
The book is well written and addresses highly contentious issues in the South African political and socio-economic domain. It is a valuable contribution to the discipline of Theological Ethics, especially the fourth part which provides perspectives on issues not usually addressed by ethicists - at least in South Africa. The book can be recommended to scholars in theological ethics, public and practical theology and also to students in the meta-theory of economic policy and business. 